\title{
Pemaknaan Penonton Mengenai Revolusi Industri 4.0 dalam Tayangan Mata Najwa Episode \#Generasisolusi
}

\author{
Thanthowie Jauharie*, Rita Gani \\ Fakultas Ilmu Komunikasi, Universitas Islam Bandung, Indonesia.
}

*tantowidj@gmail.com, rita@unisba.ac.id

\begin{abstract}
Over time, especially in the field of technology experienced very rapid progress, almost all work was helped by the role of computers and the internet. With this progress came the term Industrial Revolution 4.0, where a revolution caused by rapid technological progress. With this progress, human life has become easier, not only in working but also in meeting their needs. Appears various applications initiated by young people from various regions who want to help the community to continue to fulfill or make their lives better, which can reduce the time, energy, and costs that must be spent to meet those needs. Shown in the Mata Najwa Show episode \#GenerasiSolusi by presenting speakers who are the inventors of the Wahyoo, Halodoc, Reblood, Riliv, and CariUstadz applications. The audience did a message reception from this show about the Industrial Revolution 4.0, for its viewers it became one of the shows that provided information and education about the Industrial Revolution 4.0, they realized that the ease they had at the moment was the impact of the Industrial Revolution 4.0 marked with the emergence of various applications, after watching this show they are more aware of it and also open their minds to be more creative and critical thinking about the problems that exist in their environment. Even though not all of them received the full message given by this show, one of them did not receive the full message given, so there are two mortgage positions occupied in this research, namely dominant and negotiation.
\end{abstract}

Keywords: industrial revolution 4.0, Mata Najwa Show Episode \#GenerasiSolusi , Audience

Abstrak. Seiring berjalannya waktu terutama bidang teknologi mengalami kemajuan yang sangat pesat, hampir semua pekerjaan terbantu oleh peran komputer dan internet. Dengan kemajuan ini muncul istilah Revolusi Industri 4.0, dimana sebuah revolusi yang diakibatkan oleh kemajuan teknologi yang pesat. Dengan adanya kemajuan ini kehidupan manusia semakin mudah, tidak hanya dalam bekerja namun juga dalam memenuhi kebutuhan hidup mereka. Muncul berbagai aplikasi yang diinisiasi oleh pemuda dari berbagai wilayah yang ingin membantu masyarakat untuk terus memenuhi ataupun membuat hidup mereka lebih baik,yang dapat mengurangi waktu,tenaga, dan biaya yang harus dikeluarkan untuk memenuhi kebutuhan tersebut. Yang diperlihatkan dalam Tayangan Mata Najwa episode \#GenerasiSolusi dengan menghadirkan narasumber yang merupakan penemu dari aplikasi Wahyoo, Halodoc, Reblood, Riliv, dan CariUstadz. Para penonton melakukan sebuah resepsi pesan dari tayangan ini mengenai Revolusi Industri 4.0, bagi para penontonnya tayangan ini menjadi salah satu tayangan yang memberikan informasi dan edukasi mengenai Revolusi Industri 4.0, mereka menyadari bahwa kemudahan yang mereka miliki saat ini merupakan dampak dari Revolusi Industri 4.0 yang ditandai dengan munculnya beragam aplikasi, setelah menonton tayangan ini mereka lebih sadar akan hal itu dan juga membuka pikiran mereka untuk bisa lebih berfikir kreatif dan kritis lagi akan masalah-masalah yang ada di lingkungan mereka. Meskipun begitu tidak semua dari mereka menerima pesan sepenuhnya yang diberikan oleh tayangan ini, salah satu dari mereka tidak menerima pesan sepenuhnya dengan pesan yang diberikan, sehingga terdapat dua posisi hipotekal yang ditempati di dalam penelitian ini yaitu dominan dan negosiasi.

Kata Kunci: Revolusi Industri 4.0, Tayangan Mata Najwa Episode \#GenerasiSolusi, Penonton 


\section{A. Pendahuluan}

Istilah Industri 4.0 sendiri secara resmi lahir di Jerman tepatnya saat diadakan Hannover Fair pada tahun 2011. Revolusi industri 4.0 ini terjadi dikarenakan kemajuan teknologi yang ada ditambah juga dengan adanya bantuan internet. Dengan kemampuan komputer untuk menggerakan mesin membuat semua hal menjadi mudah dan dengan kemajuan tersebut yang memudahkan manusia untuk melakukan pekerjaan maupun memenuhi kebutuhan mereka.

Tidak hanya dalam bidang industri revolusi industri 4.0 juga merambah ke kehidupan sosial manusia yang memudahkan manusia untuk memenuhi kebutuhan mereka. Dengan bantuan koneksi internet hampir semua bisa didapatkan. Dengan kemajuan teknologi ini, muncul istilah revolusi industry 4.0 dimana hampir dalam setiap kegiatan manusia dimudahkan oleh teknologi yang ada, tidak hanya dalam pekerjaan tapi juga dalam kehidupan sehari-hari. Salah satu contoh pelayanan yang disediakan oleh aplikasi seperti Gojek tidak hanya transportasi dan makanan, tetapi juga terdapat pelayanan untuk membersihkan rumah dan mengirim paket.

Selain itu juga bila sebelumnya untuk mendapatkan berita harus berlangganan koran saat ini berita sudah bisa diakses lewat web atau media sosial, untuk menonton hiburan tidak hanya bisa lewat TV tetapi juga bisa lewat Youtube, untuk mendengarkan lagu tidak hanya di radio atau membeli CD tetapi juga bisa lewat aplikasi Spotify, yang dibutuhkan hanya koneksi internet. Dalam beberapa waktu lalu tayangan Mata Najwa mengangkat tema \#GenerasiSolusi di mana isu yang diangkat mengenai beberapa aplikasi yang ada pada zaman sekarang yang sangat memudahkan masyarakat dan berdampak besar pada masyarakat, yaitu founder dari aplikasi; Wahyoo, Halodoc, Riliv, Reblood, dan Cariustadz selain itu juga mengundang para pengguna maupun mitra dari aplikasi tersebut dan juga pengamat ekonomi dan bisnis.

Dalam tayangan tersebut disajikan proses perubahan zama yang ditandai dengan munculnya aplikasi-aplikasi tersebut dapat mempermudah masyarakat, tidak hanya mempermudah dalam memenuhi kebutuhan kita tapi juga berdampak luas bagi masyarakat lainnya.

\section{B. Landasan Teori}

Dalam penelitian ini, penulis menggunakan Teori Analisis Resepsi Stuart Hall. makna yang tersampaikan terhadap individu bisa terjadi perbedaan. Kode yang digunakan dalam pemaknaan ini ialah encode (disandi) dan decode (disandi balik). Kegiatan penerimaan pesan diawali dengan proses decoding yang merupakan kegiatan yang berlawanan dengan proses encoding. Decoding adalah kegiatan untuk menerjemahkan atau menginterpretasikan pesan-pesan fisik ke dalam suatu bentuk yang memiliki arti bagi penerima (Morissan, 2013: 21). Dalam proses tersebut tidak selamanya bersifat simetris. Dengan kata lain pemahaman dan kesalahpahaman dalam pertukaran pesan komunikasi bergantung pada encoder dan decoder. Encoder dan decoder adalah pembuat pesan dan penerima pesan. Ketika khalayak menyandi balik (decoding) dalam suatu komunikasi, maka terdapat tiga posisi hipotekal, yaitu:

1. Posisi Hegemoni Dominan, yaitu, situasi dimana khalayak menerima pesan yang disampaikan oleh media. Khalayak memaknai pesan tersebut persis seperti apa yang diinginkan oleh media.

2. Posisi Negosiasi, yaitu, khalayak menerima apa yang ingin disampaikan oleh media, namun menonlak memaknai dalam kasus - kasus tertentu. Penerimaan dalam klasifikasi ini mengandung dua hal, yaitu unsur adaptif dan oposisi. Hal tersebut menunjukan jika pesan dinegosiasikan.

3. Posisi Oposisi, yaitu, khalayak menolak pesan yang ingin disampaikan oleh media dan menggantikannya dengan cara berpikir mereka sendiri terhadap topic yang ingin disampai oleh media. Mereka menolak pesan tersebut karena tidak sesuai dengan pengetahuan atau nilai yang dianutnya. 


\section{Hasil Penelitian dan Pembahasan}

\section{Resepsi Mahasiswa Unisba Mengenai Revolusi Industri 4.0 dalam Tayangan Mata Najwa Episode \#GenerasiSolusi}

Untuk mengetahui resepsi Mahasiswa Unisba Angkata 2015 mengenai Revolusi Industri 4.0 dari tayangan Mata Najwa episode \#GenerasiSolusi, peneliti menelitinya berdasarkan dua poin yaitu, informasi dan edukasi. Informasi apakah yang mereka dapat dari tayangan Mata Najwa episode \#GenerasiSolusi mengenai Revolusi Industri 4.0 dan edukasi seperti apa yang mereka terima setelah menonton tayangan Mata Najwa episode \#GenerasiSolusi mengenai Revolusi Industri 4.0.

\section{Tayangan Mata Najwa Episode \#GenerasiSolusi Memberikan Informasi Mengenai Revolusi Industri 4.0}

Berdasarkan hasil wawancara peneliti dengan seluruh informan, mereka semua menyetujui bahwa tayangan Mata Najwa episode \#GenerasiSolusi memberikan informasi mengenai Revolusi Industri 4.0, mereka mengaku dari tayangan ini mereka lebih mengetahui tentang kemunculan aplikasi-aplikasi ini dikarenakan masyarakat saat ini telah memasuki era Revolusi Industri 4.0 selain itu mereka juga mendapatkan informasi baru mengenai aplikasi-aplikasi apa saja yang sudah ada di Indonesia dari tayangan tersebut.

\section{Tayangan Mata Najwa Episode \#GenerasiSolusi Memberikan Edukasi Mengenai Revolusi Industri 4.0}

Berdasarkan hasil wawancara peneliti dengan semua informan, mereka semua sepakat bahwa tayangan Mata Najwa episode \#GenerasiSolusi memberikan edukasi mengenai Revolusi Industri 4.0. Mereka mengaku bahwa tayangan ini mengedukasi bahwa kita sudah memasukin era Revolusi Industri 4.0 dan kita sudah dapat memenuhi kebutuhan hidup kita melalui aplikasiaplikasi yang ada, selain itu juga mereka mengaku bahwa tayangan ini mengedukasi kita untuk berfikir lebih kreatif dan kritis lagi terhadap permasalahan yang ada sehingga kita bisa mencoba untuk mencari solusinya seperti para narasumber yang hadir di tayangan Mata Najwa episode \#GenerasiSolusi.

\section{Posisi Hipotekal Mahasiswa Unisba Angkatan 2015 terhadap Tayangan Mata Najwa Episode \#GenerasiSolusi}

Berdasarkan hasil wawancara peneliti dengan seluruh informan, peneliti berhasil menemukan informan yang menonton tayangan Mata Najwa episode \#GenerasiSolusi, mereka menduduki dua posisi hipotekal yang berbeda. Empat dari mereka menduduki posisi dominan karena menerima penuh pesan yang disampaikan dari tayangan Mata Najwa episode \#GenerasiSolusi dan hanya satu dari mereka yang menduduki posisi negosiasi, karena adanya perbedaan

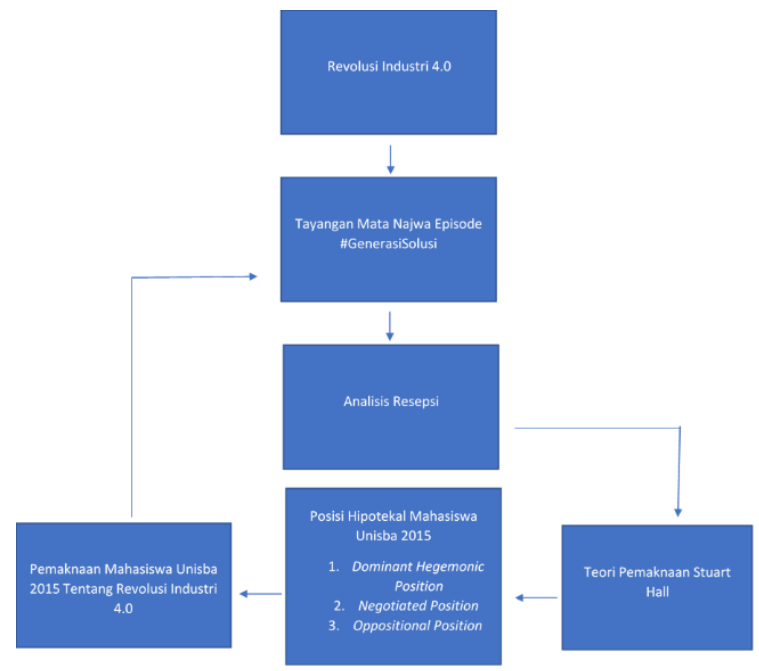

Gambar 1. Kerangka Pemikiran 
pikiran akan konsultasi online dengan dokter, informan merasa untuk konsultasi dengan dokter lebih baik dilakukan secara langsung dan tidak ada yang menduduki posisi oposisi. Peneliti melihat hal tersebut dari jawaban-jawaban mereka saat peneliti wawancara.

\section{Kesimpulan}

Berdasarkan hasil temuan dan pembahasan dalam penelitian ini, dapat ditarik simpulan sebagai berikut:

1. Melalui tayangan Mata Najwa episode \#GenerasiSolusi pengetahuan Mahasiswa Unisba Angkatan 2015 mengenai Revolusi Industri 4.0 juga bertambah, mereka yang sebelumnya hanya menggunakan aplikasi-aplikasi yang tersedia di Hp mereka tanpa mengetahui bahwa kemudahan yang mereka dapat adalah sebuah dampak dari Revolusi Industri 4.0 .

2. Mereka juga menyadari bahwa di era ini kemudahan yang dikatakan di tayangan tersebut juga benar adanya, karena mereka sudah mengalami dan mencoba beberapa kemudahan yang didapat melalui aplikasi-aplikasi yang mereka gunakan. Mereka mendapatkan akses untuk memenuhi kebutuhan hidup sehari-hari mereka baik dalam lingkungan kampus,pekerjaan, atau sosial mereka bisa dapatkan hanya dengan mengakses $\mathrm{Hp}$ mereka, asalkan terkoneksi dengan internet.

3. Selain itu, tayangan ini juga memberikan informasi bagaimana anak muda bangsa mencoba untuk menyelesaikan permasalahan yang ada di lingkungannya dengan mencoba untuk berfikir lebih kreatif dan kritis lagi, yang dibantu juga oleh program pemerintah yang ada, salah satunya di Kota Surabaya yang kebetulan menjadi Kota awal munculnya aplikasi Riliv dan Reblood.

4. Sehingga tayangan ini dirasa dapat menjadi edukasi bagi para penontonnya agar mereka sadar bahwa kita sudah memasuki era 4.0 ini dan kita tidak boleh tertinggal dengan kemajuan ini, karena mungkin apabila kita tidak mengikuti perkembangan jaman ini malah kita yang rugi sendiri.

5. Empat informan menduduki posisi dominan yakni yang menerima penuh pesan yang disampaikan oleh tayangan Mata Najwa episode \#GenerasiSolusi. Mereka setuju dengan pesan bahwa aplikasi-aplikasi ini memudahkan kehidupan sehari-hari mereka dan sangat mengefisiensikan waktu yang mereka punya, sehingga yang tadinya mereka sebelumnya apa-apa memakan waktu yang cukup lama dengan hadirnya aplikasi aplikasi ini dapat memangkas waktu tersebut.

6. Sedangkan Sharah informan yang berasal dari Fakultas Kedokteran juga menyetujui kemudahan yang didapat dari aplikasi-aplikasi ini. Hanya saja dia memiliki pemikiran lain terkait konsultasi secara online dengan dokter melalui aplikasi Halodoc. Menurutnya untuk konsultasi dengan dokter alangkah lebih baiknya dilakukan secara langsung bukan secara online, karena dokter harus melihat kondisi fisik pasiennya untuk dapat mendiagnosis penyakit sang pasien secara benar. Sharah mengkhawatirkan apabila dilakukan secara online diagnosis yang diberikan salah atau kurang tepat.

\section{E. Saran}

\section{Saran Teoritis}

Penelitian ini berisi tentang resepsi yang muncul dari Mahasiswa Unisba Angkatan 2015 mengenai Revolusi Industri 4.0 dalam tayangan Mata Najwa episode \#GenerasiSolusi, maka dari itu peneliti menyarankan bagi siapa pun yang ingin melakukan penelitian sejenis agar menitikberatkan pada cara khalayak memaknai pesan yang disampaikan oleh suatu media melalui infografis.

\section{Saran Praktis}

1. Saran peneliti dari penelitian yang peneliti lakukan adalah, jangan lupa untuk terus mengetahui perkembangan yang ada di lingkungan kita. Agar kita bisa lebih tahu lagi tentang apa yang sedang terjadi di lingkungan kita atau kemajuan teknologi sudah sampai 
mana. Dengan begitu kita dapat untuk lebih kritis dan berfikir kreatif untuk mencari solusi dari masalah yang ada.

2. Terutama pihak kampus juga harus bisa mempersiapkan mahasiswa-mahasiswa agar bisa bersaing di zaman yang sedang berkembang ini, karena itu merupakan salah satu tugas adanya kampus itu sendiri. Untuk mempersiapkan mahasiswa untuk jenjang yang lebih lanjut.

\section{Daftar Pustaka}

[1] Morissan. 2013. Teori komunikasi : individu hingga massa . Jakarta : Kencana

[2] Mulyana, Deddy. 2014. Ilmu Komunikasi. Bandung: Remaja Rosdakarya.

[3] Prasetyo, Hoedi. \& Sutopo, Wahyudi. (2018) Industri 4.0: Telaah Klasifikasi Aspek Dan Arah Perkembangan Riset 